Check for updates

London

Cite this as: BMJ 2021;375:n2535 http://dx.doi.org/10.1136/bmi.n2535 Published: 15 October 2021

\section{Covid-19: PCR testing is suspended at private laboratory after high rate of false negatives}

\author{
Ingrid Torjesen
}

Testing for covid-19 has been suspended at a private laboratory in Wolverhampton after an investigation by the UK Health Security Agency into media reports of a spike in the number of people receiving negative PCR test results after they had tested positive for covid-19 on a lateral flow device (LFD).

The increase has been seen over several weeks, raising questions over why the laboratory's quality control processes and those of NHS Test and Trace did not pick up the problem earlier. There are also questions concerning how many people who underwent PCR testing without an LFD result, such as contacts of people with positive cases and travellers returning from overseas, might also have been given negative results when they were actually infected.

Data from the Health Security Agency show that the proportion of negative PCR test results matched to a positive results of an LFT taken at a test site centre shot up in the week starting 2 September to 20\% (959 of 4748 ) and to $17 \%$ (65 of 380 ) in the week starting 23 September, from 10\% (44 of 441) in mid-August. ${ }^{1}$

In terms of LFTs taken at home, the number of positive tests matched to a negative result on PCR rose gradually from $8 \%$ (4457 of 53 252) in mid-July to $13 \%$ (3473 of 27662 ) in mid-September and $15 \%$ (6492 of 42472 ) in the week starting 23 September, the latest period for which results are available.

A spokesperson for NHS Test and Trace said that around 400 ooo samples had been processed by the laboratory and that an estimated 43 ooo people, mostly living in the South West of England but also in the South East of England and Wales, may have been given incorrect negative PCR test results between 8 September and 12 October.

An investigation into the precise cause of the false negative results at the facility in Wolverhampton run by Immensa Health Clinic is still ongoing. Immensa is part of Dante Laboratories, which provides covid-19 testing services geared towards departing and returning international travellers.

Will Welfare, public health incident director at the Health Security Agency, said, "We have recently seen a rising number of positive LFD results subsequently testing negative on PCR. As a result of our investigation, we are working with NHS Test and Trace and the company to determine the laboratory technical issues which have led to inaccurate PCR results being issued to people. We have immediately suspended testing at this laboratory while we continue the investigation.

"There is no evidence of any faults with LFD or PCR test kits themselves, and the public should remain confident in using them and in other laboratory services currently provided.”

Sheila Bird, formerly programme leader at the MRC Biostatistics Unit at the University of Cambridge, said the issue was identified through PCR adjudication of LFT positive tests and through journalists' reporting and that it was unclear whether the laboratory's and Test and Trace's quality control systems had failed to detect that there was a problem. It was also unclear whether the problem was more widespread.

She asked, “Does the 'problem' affect PCR tests done for persons without LFT positive antecedent, who include citizens who have developed symptoms; who have been identified as close contacts of index infected persons and are following advice to seek immediate PCR; or are international travellers arriving into or back to UK?"

UK laboratories process around 800 ooo PCR tests a day.

NHS Test and Trace is contacting people who may have been and could still be infectious to advise them to take another PCR test. Close contacts who are without symptoms will also be advised to take a test, in line with normal practice.

Andrea Riposati, chief executive officer of Immensa Health Clinic, said, "We are fully collaborating with UKHSA on this matter. Quality is paramount for us. We have proudly analysed more than 2.5 million samples for NHS Test and Trace, working closely with the great teams at DHSC and UKHSA. We do not wish this matter or anything else to tarnish the amazing work done by the UK in this pandemic."

Tests conducted at Newbury Showground testing site were among those affected. West Berkshire Council said that it received reports from local residents in recent weeks that there were concerns about the accuracy of tests conducted there. It is urging anyone who took a PCR test there between 3 and 12 October and who received a negative result to be retested and is recommending that their close contacts also get tested, because they may still be infectious.

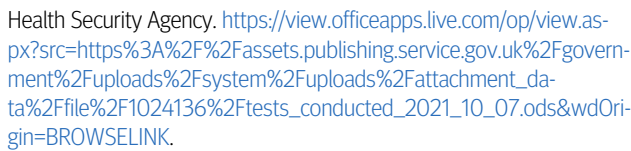

This article is made freely available for use in accordance with BMJ's website terms and conditions for the duration of the covid-19 pandemic or until otherwise determined by BMJ. You may use, download and print the article for any lawful, non-commercial purpose (including text and data mining) provided that all copyright notices and trade marks are retained. 